TIPA. Travaux interdisciplinaires sur la parole et le langage

37 | 2021

La convergence

\title{
Convergence and secondary entropy in a macrodiachronic perspective
}

Convergence et entropie secondaire dans une perspective macrodiachronique

\section{Cyril Aslanov}

\section{(2) OpenEdition \\ 1 Journals}

Electronic version

URL: https://journals.openedition.org/tipa/4125

DOI: $10.4000 /$ tipa. 4125

ISSN: 2264-7082

Publisher

Laboratoire Parole et Langage

\section{Electronic reference}

Cyril Aslanov, "Convergence and secondary entropy in a macrodiachronic perspective", TIPA. Travaux interdisciplinaires sur la parole et le langage [Online], 37 | 2021, Online since 23 July 2021, connection on 20 October 2021. URL: http://journals.openedition.org/tipa/4125 ; DOI: https://doi.org/10.4000/tipa. 4125

\section{(c) (i) (9)}

La revue TIPA. Travaux interdisciplinaires sur la parole et le langage est mise à disposition selon les termes de la licence Creative Commons Attribution - Pas d'Utilisation Commerciale - Pas de Modification 4.0 International. 


\title{
Convergence and secondary entropy in a macrodiachronic perspective
}

\author{
Cyril Aslanov \\ Aix-Marseille Univ, CNRS, LPL, Aix-en-Provence, France / Institut Universitaire de France \\ msaslan@mail.huji.ac.il
}

In the past decades, the theory of secondary convergence and entropy has been convincingly applied to the methodology of comparative linguistics. Thus, it has had interesting results in the comparative linguistics of Semitic languages, first by Garbini with his theory of the constitution of a Semitic language family as a result of the Amorite invasions in the Middle East and the subsequent Amoritization of the languages spoken in the area; then, in a more cautious and detailed way, by Lutz Edzard who analyzed the secondary convergence between various Semitic languages once they were already distinguished from one other as separate branches deriving from the same proto-language (Edzard, 1998). However, Edzard's contribution to the issue of secondary convergence only regards languages of the same family, the Semitic one, a relatively small language family and briefly, the Chamito-Semitic loose family.

In the field of Indo-European comparative linguistics, a model based on the principle of hybridization has been proposed in the frame of the stratigraphic studies pioneered by the Slavist Henning Andersen with an original approach based on the perception of linguistic systems as composite structures whose elements develop in a differential way with different paces of linguistic change and various degrees of exposure to other languages of the IndoEuropean family.

Though inspired by Andersen's conception of the linguistic system as composite and differentially impacted by diachronic evolution and language contact, the present study differs therefrom, since it analyses the outcomes of the contact of late Proto-Indo-European with allogenic languages in an attempt to reconstruct some decisive changes in the crystallization of the historically attested Indo-European languages.

However, I propose to take further this trend that consists in challenging the principle of ramification by a model based on the idea of mutual convergence between several focuses. My assumption is that at an early stage of PIE, the dynamics of entropy and convergence could also have been at play between languages of different origin, not only between branches of the same linguistic family. The question is whether the contact of various subdivisions of Proto-IndoEuropean with allogenic languages could be perceived from a different perspective: not only as

TIPA. Travaux interdisciplinaires surr la parole et le langage, 37 I 2021 
a centrifuge process with respect to PIE, but also as a centripetal process, by way of which initially non-IE languages were eventually Indo-Europeanized.

\section{Mutual convergence between Hittite and the Semitic languages}

The Anatolian branch of Indo-European languages, whose earliest attested representative is Hittite, provides a fascinating example of a language deeply integrated in a Middle Eastern Sprachbund. I shall try to analyze the dynamic of convergence and hybridization that brought close to each other Hittite, the most anciently attested Indo-European language, and Semitic languages from the second millennium BC, namely Ugaritic and Akkadian. As a matter of fact, the contact between Akkadian and Hittite goes back to the twentieth century BC, as attested by the sporadic presence of Hittite loanwords and given names in Akkadian (Old Assyrian) texts (Dercksen, 2007).

\section{Phonology}

The cuneiform script is not always very helpful to understand the phonology of Anatolian languages. However, other Anatolian languages like Lycian and Lydian are attested at a later stage and are written with a derivate of the Greek alphabet that is easier to read than the oftenequivocal cuneiforms. Anyway, the main features of the Anatolian phonemic system have been successfully reconstructed. Within this system such as it is commonly reconstructed, I will try to perceive the traces of a systemic hybridization with non-IE substrata or with adstrata pertaining to the Middle Eastern Sprachbund.

vowels

There are some pieces of evidence as to the belonging of Hittite to a Middle Eastern Sprachbund. First of all, the reflex of Proto-Indo-European *[o] as [a] is reminiscent of the Indo-Iranian shift of Proto-Indo-European mid-vowels *[e] and *[o] to *[a]. However, a vowel $[\mathrm{o}] /[\overline{\mathrm{o}}]$ that does not necessarily continue Indo-European *[o] exists in Hittite even though it is represented by spelling conventions involving the use of cuneiforms of the $-u$ range, the $-u$ range specifically representing $[\mathrm{u}] /[\overline{\mathrm{u}}]$ (Rieken, 2011; 56-57).

\section{consonants}

Features more specific and more focused on Semitic languages are displayed by the consonantal system of Hittite. One of them is the preservation of Proto-Indo-European $*\left[\mathrm{H}_{2}\right]$ and $*\left[\mathrm{H}_{3}\right]$ not only in Hittite, but also in the main representatives of the Anatolian group of Indo-European languages. By itself, this fact is noteworthy because it shows that this conservatism is not necessarily to be ascribed to the very high antiquity of Hittite. Lycian, a language that survived 
until approximately the beginning of the first century BC, also maintained the consonantal value of the laryngeal as shown by the word $\chi a v \tilde{a}-$ "sheep" < Indo-European ${ }^{*} H_{2}$ ówis (cf. Luwian $h \bar{a} w \bar{l}-)$. The contact with some Northwest Semitic languages, whose phonemic system contains a full set of laryngeal (glottal) and pharyngeal phonemes, may explain why the laryngeal $*\left[\mathrm{H}_{2}\right]$ and $*\left[\mathrm{H}_{3}\right]$ preserved their consonantal value in Anatolian languages while in the other IndoEuropean languages they were reinterpreted as vocalic coefficients or simply dropped (Rasmussen, 1999; 67-81). Admittedly, the consonantal value was indirectly conserved in the aspiration of the 2 nd pers. sg. ending of the perfect in Sanskrit (-tha) and Greek $(-\theta \alpha)$ where the aspiration of the dental consonant constitutes the last trace left by the laryngeal of the ProtoIndo-European ending $*$ - $t \mathrm{H}_{2} e$. One could also mention the verbal adjective ${ }^{*} s t H_{2} t o ́ s$ of the root

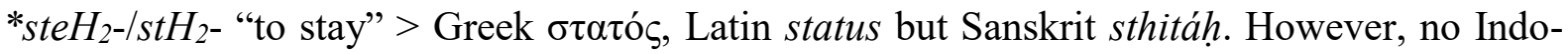
European language outside the Anatolian branch seems to have preserved the consonantal value of the laryngeals per se and not only the reflexes of their former presence, as in the case of Sanskrit (-tha) and Greek $(-\theta \alpha)$.

If one assumes with Rasmussen that $*\left[\mathrm{H}_{1}\right]$ was a glottal $[\mathrm{h}]$, then its disappearance in Anatolian could be interpreted as an interesting case of convergence toward the Semitic languages where [h] (Hebrew and Syriac $h \bar{e}$; Arabic $h \bar{a}$ ') tends to be dropped in the substandard pronunciation of many languages and dialects. As for $*\left[\mathrm{H}_{2}\right]$ and $*\left[\mathrm{H}_{3}\right]$, whose original values according to the same Rasmussen were probably the uvulars $[\mathrm{x}]$ and $\left[\gamma^{\mathrm{w}}\right]$, respectively, they could have been preserved thanks to the contact with archaic Semitic languages like Ugaritic where the uvulars $*[\mathrm{x}]=*[\mathrm{~h}]$ and $*[\gamma]=*[\dot{\mathrm{g}}]$ (without the labiovelar appendix) existed before they merged with pharyngeal [h] and [C], respectively, in Canaanite and in Aramaic. Even the contact with Akkadian can give an account of the preservation of $*\left[\mathrm{H}_{2}\right]$ since in this eastern Semitic language where most of the pharyngeal and laryngeal (glottal) consonants disappeared, there was still a uvular [h], whose graphic representation, that is, the syllabograms $<$ ha $>$, $<$ he $>,<$ hi $>$, $<$ hu $>$, $<\mathrm{ah}>$, served for the notation of the Hittite reflections of $*\left[\mathrm{H}_{2}\right]$ and $*\left[\mathrm{H}_{3}\right]$.

Lastly, Hittite displays an interesting development that affected the consonantal system and can be considered an additional indication of the integration of this language into the Middle Eastern Sprachbund. It is the frequent alternation between [w] and [m]. Interestingly enough, in Semitic languages, this change did not have any morphological implication whereas in Hittite it seems to have been mostly restricted to the verbal endings. Let us enumerate three occurrences of this alternation:

1. Proto-Indo-European *-men- $i$, the primary ending of the 1 st pers. pl., where it is possible to recognize the element *-men, extended by the morph $*_{-i} i$ found in Greek $\lambda \varepsilon \dot{\varepsilon} \varepsilon-1$ (as against the imperfect $\varepsilon \bar{\varepsilon} \lambda \gamma \varepsilon$ ), becomes -weni in Hittite. There is no point to relate this ending -weni of Hittite with the pronoun wěs "we" (<Proto-Indo-European *wei-es). Indeed, *-men- is perfectly understandable in terms of Proto-Indo-European verbal morphology since it is one of the three alternating forms of the morph of the 1 st pers. pl. *-mes $/{ }^{*}-m o s /{ }^{*}-m e n$. The shift Proto-Indo- 
European ${ }^{*}-m e n-i>$ Hittite $-w e n i$ is likelier to be a secondary phenomenon, probably as a consequence of the structural drift shared with Semitic languages, especially Akkadian, where $[\mathrm{m}]$ and $[\mathrm{w}]$ often alternate with each other, maybe partly for graphemic reasons (Talon, 2010). This view is not shared by Elisabeth Rieken who considers that the shift is from -weni to -meni and that it is originally due to a phenomenon of dissimilation when the preceding vowel is $[\mathrm{u}]$ (Rieken, 2011: 59). This view reflects an analysis of the system from a synchronic point of view that does not take in account the likeliest etymology of the ending -weni/-wen from Proto-IndoEuropean *-men.

2. Proto-Indo-European *-men, the secondary ending of the 1 st pers. pl., becomes -wen in the paradigm of the Hittite preterit.

3. Proto-Indo-European ${ }^{*}-m e s d^{h} H_{2}$, the ending of the mediopassive 1 st pl., becomes -wašta in Hittite.

As mentioned above, the alternation between [w] and [m] is well attested in ancient Semitic language where it can work in the two directions: sometimes Northwest Semitic [m] is paralleled by Eastern Semitic [w]; some other times, it is the other way around. Let us quote, for instance, Ugaritic 'argmn, Hebrew 'argāmān "purple" on the one hand and Neo-Babylonian argawannu "purple", Aramaic 'argəwānā (under the influence of Neo-Babylonian) on the other. Conversely, Akkadian simānu "season" alternates with Aramaic siwān "name of the month". In some instances, the alternation between [w] and [m] occurs not only between Akkadian and Northwest Semitic but even within the Northwest Semitic branch as shown by the alternation between Hebrew Yāwān "Ionia" on the one hand and Ugaritic Yman as Akkadian Yaman on the other hand. No doubt that Hebrew is closer to the Greek etymon 'I⿳亠丷厂 F $\omega v$ already attested in Mycenaean: $i$-ja-wo-ne = 'I⿳亠丷厂́Foves (Ventris \& Chadwick, 1973: 547).

\section{Morphology}

\section{nominal morphology}

In Northwest Semitic languages, the allative in $-(\bar{a}) h$ is probably the result of the vocalization of the so-called he locale, as shown by the spelling of the terminative morph in Ugaritic (Speiser, 1954; Tropper, 2000: 320-325). In Hittite, the allative ending - $a$ (Kammenhuber, $1979)$ displays some similarity with this West Semitic terminative - $(\bar{a}) h$. Since this ending does not seem to be connected with the accusative ending $-n /$-an and in absence of a clear IndoEuropean origin for this isolated ending, I suggest considering the directive - $a$ a borrowing from Northwest Semitic. Indeed, it could result from a reinterpretation of the Semitic terminative $(\bar{a}) h$ as $-a$. In West Semitic, this ending was a consonant $-h$ vocalized $-\bar{a} h$, as mentioned above. What could have been retained once the ending was integrated in Hittite was the vocalic resonance, not the $[\mathrm{h}]$ that did not exist in the phonemic system of Hittite. Indeed, the laryngeal [h] $\left(<\right.$ Proto-Indo-European $\left.{ }^{*} H_{2}\right)$ seems to have been of another nature, pharyngeal or uvular 
rather than glottal. This is all the likelier in that the Indo-European etymology that consists in considering Hittite $-a$ the reflex of an Indo-European $*_{-} \bar{o}$ represented by the $-\omega$ in Greek $\varepsilon$ li $\sigma \omega$ "inside" and $\varepsilon \xi \omega$ "outside" or by Latin $q u \bar{o}$ ? "where to" is not so satisfying (Laroche, 1970: 46). According to Eduard Schwyzer, this $-\omega$ ending of the adverbs is a late refection (Nachbildung) on the model of the adverbial ending $-\omega(\varsigma)$, itself a recycling of an ancient instrumental in $-\omega<$ Proto-Indo-European *-o (Schwyzer, 1953: 550). As for George Dunkel's hypothesis that consists in recognizing in the allative ending - $a$ of Hittite a postposed adverb *$o$ that became part of the paradigm it is certainly very seducing (Dunkel, 1994). However, it relies on a very complex scaffolding of concatenated assumptions involving thin facts grabbed from Sanskrit, Greek and Italic. Therefore, I still consider the assumption as to the borrowing of a North-West Semitic terminative ending more economic than Dunkel's subtle (maybe too subtle?) reconstruction.

Moreover, the eventual merger of directive and dative-locative in Luwian and other Anatolian languages displays a common structural feature with West Semitic (mostly Ugaritic and Hebrew) where the form suffixed with the terminative ending $-(\bar{a}) h$ can permute with the dativelike form built with the preposition lo-. In Luwian, the merger is even more blatant as it seems to be illustrated by the very way one of the endings of the dative (the dative of proper nouns in -a) (Yakubovich, 2015) is structured: -iya, that is, a probable combination of the dative-locative ending $-i$ with the allative ending $-a$. Whereas the allative- and dative-like complements in West Semitic appear to be in a complementary distribution, Luwian agglutinated the dative $-i$ and the $-a$, combining the two exclusive options as -iya.

How to interpret this curious presence of a probably allogeneous component within the core of the grammatical system of the language? The most economical way of justifying such hybridization is to assume that at a certain stage of the development of the Anatolian languages, a situation of Hittite-Northwest Semitic bilingualism allowed the integration of a useful morphological tool within the nominal declension.

Lastly, even if the adoption of a declension ending seems to be an uncommon phenomenon in terms of typology, it is perhaps less unlikely with the specific morphological category of allative-terminative that was used with full-fledged toponyms or common names used as place names. Due to the contact between speakers of Ugaritic and Hittites, some place names containing the terminative morph $-\bar{a}(h)$ could have been integrated, sometimes with this specific morph, some other times in the bare form. From the Ugaritic-borrowed place names, this mechanism that consists in alternating toponyms containing the allative morph $-\bar{a}(h)(-a$ in Hittite) with bare toponyms could have been extended to the properly Hittite stocks of toponyms and from there to common names used as place names like arun- $a$ "to the sea" or nepiš- $a$ "to the heaven". 
Another interesting point of convergence between Hittite and Semitic languages is the postposition of the possessive. Admittedly, the exact functioning of the possessive is quite different. In the Semitic languages, the possessive suffix varies only according to the person of the possessor, whereas in Hittite, it is a full-fledged adjective that agrees in number and case with the noun. However, this adjective displays a particularity that makes it very similar to the Semitic suffix. In Old Hittite, at least, it enjoys the status of an enclitic postponed to the noun, which is very reminiscent of the Semitic construction: cf. Hittite išhašs-miš like Akkadian bēl-ī "my lord". The reason for this mimetism may be due to the fact that many nouns are written with ideograms (Akkadograms) containing the sequence noun + possessive suffix. Whatever the reason for the influence might be - either a living bilingualism or the pressure of an inherited writing system on the very structure of the language, it is highly probable that this syntactic structure results from the impregnations of a Semitic model on the morphosyntactic mechanism of the Hittite language. It is worth noting that in the same Middle Eastern Sprachbund, other languages like Hurrian (Friedrich, 1969a: 15; Wegner, 2000: 54-56) and Urartian (Friedrich, 1969b: 41) display the same tendency that consists in using a postposed possessive.

Interestingly enough, a more Indo-European word order within the noun phrase is attested in later phases of the development of Hittite where a set of pronouns in genitive derived from the personal pronoun precede the noun: ammel; tuel/twel; apel; anzel; šumel, that is, "my", (literally "of me"); "thine" (literally "of thee"); "his/her" (literally "of him/her"); "our" (literally "of us"); "your" (literally “of you”), respectively. While Émile Benveniste assigned an IndoEuropean etymology to this morph -el, he stressed that it does not belong either to the nominal or to the pronominal Indo-European flexion and rather functions as an adverbial suffix (Benveniste, 1953). According to Heinz Kronasser, however, this suffix -el was probably extracted from Hattic by way of a morphological analogy (Kronasser, 1966: 235-236).

A similar impact of the Akkadian writing system on word formation is provided by the feminine noun haššušara- "queen", a compound name composed of haššu- "king" and of the Akkadian noun šaratu. This hybrid word formation seems to constitute a possible reading of the Sumerogram MUNUS.LUGAL "woman-king” but with a Semitic word order whereby the head haššu- "king" precedes the modifier šara- $(<\check{s} a r a t u)$. There is only a slight semantic shift inasmuch as in Sumerian, the determining MUNUS is a generic term for a woman in general, whereas in Akkadian, šaratu already means "queen". Thus, the literal meaning of Hittite haššššara < hašš u- + šaratu is "king (who is a) queen". Interestingly enough, this hybrid compound is handled as a form in the genus commune and receives the nominative sg. ending -š: hূǎ̌šušaraš.

There might be another mark of hybridization in the nominal system of Hittite. It is the use of a suffix -it in some words referring to basic kinds of food: Hittite melitt-/militt-; Luwian mallit"honey"; Hittite šeppitt- "a kind of wheat". 
Though the Hittite form melitt-/militt- has parallels in other Indo-European languages (Greek $\mu \varepsilon \dot{\lambda} \mathrm{\imath} / \mu \varepsilon \dot{\lambda} \imath \tau$ s;; Gothic milip; Albanian mjaltë), it is worth noting that no convincing IndoEuropean origin has been found for this extension morph $-t$. Admittedly, the root itself ( $\left.{ }^{*} m e l\right)$ is attested in other Indo-European languages: Latin mel; Irish mil; Armenian utinn metr. However, the specific base of derivation with the -it extension is attested only in Anatolian, Greek, Albanian and Germanic.

Moreover, if one considers the syllabic structure of the Hittite form melit- or of an IndoEuropean etymon *mel-it, it does not fit the expected pattern whenever a CVC- root is extended by a consonantal suffix. Here what should have been expected is something like *mel-t according to the usual CVC-C scheme. The $-i$ - defies our understanding of Indo-European stem formation and could therefore be associated with a foreign, alien origin. Thus, the form mel-it that is attested in Hittite and Luwian and can be reconstructed through Greek, Gothic and Albanian, could be the result of the combination of an Indo-European root ( $*_{m e l)}$ with a suffix of non-IE origin. It would be tempting to recognize it as a morphological borrowing from Hattic, a language where -it seems to have functioned as a suffix of derivation of feminine entities from a noun: Arinna (name of a sanctuary) $\longrightarrow$ Arin-it "the female goddess of Arinna" (Justus, 1992); Hanwasu-it "throne-goddess" (literally "throne dais") Tahatenuit, name of

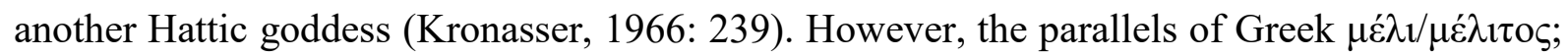
Gothic milip; Albanian mjaltë may weaken the assumption that the element -it is of Hattic origin since the borrowing of a Hattic morph is expected to interest mostly Hittite, the language that superseded Hattic and had the latter as its substratum. The fact that Greek, Albanian and Gothic share the element -it in the same lexical item could suggest looking for another origin for this morph, something broader than Hattic.

Interestingly enough, the Semitic origin of the suffix -it in Anatolian has been indirectly recognized, though in a different way, by Adam Hyllested's etymology for Hittite šeppitt-. According to this scholar, this term represents a direct borrowing from a Semitic language: either Akkadian samīdu or Aramaic semīd "high quality wheat flour". According to his assumption, the element -itt of šeppitt- represents the -īd element of samìd-u/semìd which could have been reinterpreted as a morphological coefficient in the creation of the analogical forms *alb ${ }^{h}$-it, whence Greek ó $\lambda \varphi \imath \tau o v$, and *mél-it (Hyllested, 2020). However, the possibility of abstracting an otherwise unknown morpheme from the semantic word seems too far-fetched. Such a misanalysis could make sense only if a suffix -it already exists among the morphological devices of a given language. In other words, the attempt at bypassing the assumption as to the existence of the suffix -it still implicitly recognizes the existence of such a suffix.

With regard to Anatolian, and to a certain extent to Greek, the possibility of contact with Semitic languages is highly plausible. Illyrian, the putative ancestor of Albanian, seems to be a little bit more far away from such contact. However, this language is united by many structural and

TIPA. Travaux interdisciplinaires surr la parole et le langage, 37 I 2021 
lexical isoglosses with Greek, probably as a result of the belonging of both Greek and Illyrian to the first Balkan Sprachbund, at a time that preceded the migration of the Hellenes to Hellas.

As for Gothic milip, it could be a Greek loanword in Gothic itself. Let us remember that the genuine Germanic word *xunangan (High Old German honang) for honey is precisely related to the Proto-Indo-European etymon $* k_{2} H_{2}$ ónks $/ k_{n} H_{2} k o ́ s$. In other words, the use of milip could be viewed as a pressure exerted by the source language of the Greek Vorlage of Ulfila's translation on Gothic, the target language. Therefore, it may be tempting to consider the -it element in Hittite melitt/militt-; Luwian mallit- "honey" and in its Greek counterpart $\mu \varepsilon \dot{\lambda} \lambda / \mu \varepsilon \dot{\lambda} \imath \tau o \varsigma$ a morphological borrowing from Northwest Semitic languages where the element -it functions as a feminine ending. Actually, the same morphological device is attested in

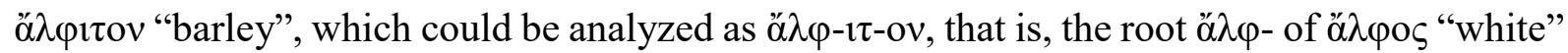
with a suffix $-\imath \tau$. This analysis does not contradict my assumption as to a Semitic origin of the suffix -it. Indeed, Greek is one of the Indo-European languages where the structural influence exerted by Semitic languages has been the deepest and the strongest (Aslanov, 2013).

It is worth noting that the Hittite words melitt-/militt- and šeppitt- together with Greek $\alpha \dot{\alpha} \varphi \iota \tau o v$ belong to the semantic field of agriculture. Admittedly, judging from the reconstruction of the propagation of the farming culture from the Fertile Crescent northwards to Greece and the Balkans (c. $6500 \mathrm{BC}-$ c. $5800 \mathrm{BC}$ ) (Cunliffe, 2008), it is likely that the innovation consisting in cultivating barley and šeppitt- and to produce honey was adopted at a very early time before the IE-speaking people began to expand in the direction of Asia Minor and the Balkans and even before the spreading of Semitic languages in the Fertile Crescent (according to a scenario that rejects Sturtevant's hypothesis regarding Asia Minor as the homeland of Proto-IndoEuropean at such an old date as the seventh millennium BC). Nevertheless, it could be that a full-fledged domesticated beekeeping and the use of the specific cereal known as šeppitt(maybe wheat) in Hittite correspond to a later stage of the transfer of farming technology from the Fertile Crescent to Indo-European speaking people, either in Asia Minor and the Balkans, or perhaps at the beginning of the expansion of the Corded Ware/Single Grave Culture outside the Pontic-Caspian Steppes. If the latter assumption is true, the presence of the suffix -it in Albanian and Gothic words connected with "honey" is easier to understand, especially if one takes into account that - it is attested with another root in Tocharian, an Indo-European language quite remote from the contact zone between Indo-European and Semitic languages. Indeed, Douglas Adams calls "food suffix" this suffix -it that he recognizes in the form *yewit (Pinault, 2008: 371), the etymon of Tocharian B yap "barley" (Adams, 2013: 54).

With time, however, the semantic part of the word was replaced with Indo-European lexical material by way of a process of relexification. However, the suffix -it could have been kept as a kind of classifier reminiscent of the foreign origin of those imported agricultural items and of the lexical borrowings that first referred to them. Thus, the suffix -it could have been adapted to Indo-European roots * $H_{2} e l-b h$ - of $\alpha \hat{\lambda} \lambda-\varphi-\imath \tau-o v$, also recognizable in Albanian elb "barley". 
Thus, it is likely that Anatolian languages functioned as an important stage in the acclimatization of the suffix -it. Since those languages did not know the distinction between masculine and feminine, the originally feminine ending -it could have lost its specific gender to be recycled as a morph of inanimate.

\section{verbal morphology}

The Hittite verbal system is a highly polymorphic system where variants coexist according to a rationale that is not always easy to grasp. This polymorphy is further complicated by a certain amount of lability of the boundaries between Hittite and Luwian as far as the use of some verbal endings is concerned, like the occasional use of -nti, the Luwian ending of the 3rd pers. pl., instead of Hittite -nzi (Kronasser, 1966: 589).

I would like to go further in this analysis of the permeability of the Hittite verbal system, considering that the whole verbal system of Hittite displays a set of affinities with Akkadian. If one bears in mind the old stative value of the Proto-Semitic perfect, which is witnessed by the Akkadian stative, it would be possible to consider that the almost complete identity between a diathetic category (the Hittite mediopassive present) with an aspectual-temporal one (the ProtoIndo-European perfect) (Jasanoff, 1978: 15) is a clear indication of a Semitic influence on the whole system of the Hittite verb. Moreover, it is important to stress that the Hittite mediopassive perfect seems to be a secondary formation on the basis of the mediopassive present. The mediopassive present and the mediopassive perfect share the same stem and differ only through the adjunction of a secondary ending that functions as a coefficient that seems to express the contrast between the present and the perfect in the mediopassive of ar-ha- "I stand": present ar-ha-ri vs. perfect *ar-ha-ti (Yoshida, 1990).

In the 2nd pers. sg., there is even an overlapping between the present and the perfect as the same form artati "you stand; you stood" can be used instead of the differentiated forms artari "I stand" vs. artat "I stood". The following table inspired by Elisabeth Rieken's descriptions (Rieken, 2011: 105) will summarize the dynamics that consist in creating two distinct paradigms through the adjunction of a secondary ending functioning as an extension:

\begin{tabular}{|l|l|l|}
\hline & mediopassive present & mediopassive perfect \\
\hline 1st pers. sg. & $\begin{array}{l}\text { ar-ha-ri } \\
\text { ar-haha-ri (Yoshida, } \\
2013: 164-170)\end{array}$ & *ar-ha-haha-ti \\
\hline
\end{tabular}

TIPA. Travaux interdisciplinaires surr la parole et le langage, 37 I 2021 


\begin{tabular}{|c|c|c|}
\hline \multirow[t]{2}{*}{ 2nd pers. sg. } & $a r-t a-r i$ & $a r-t a-t$ \\
\hline & \multicolumn{2}{|l|}{$a r-t a-t i$} \\
\hline 3rd pers. sg. & $\begin{array}{l}\text { ar-ta } \\
\text { ar-ta-ri }\end{array}$ & $a r-t a-t$ \\
\hline 1st pers. pl. & ar-wašta & ar-wašta-t \\
\hline 2nd pers. pl. & *ar-tuma-ri & *ar-duma-t \\
\hline 3rd pers. pl. & $\begin{array}{l}\text { ar-anta } \\
\text { ar-anta-ri }\end{array}$ & $\begin{array}{l}\text { ar-anta-t } \\
\text { ar-anta-ti }\end{array}$ \\
\hline
\end{tabular}

It should be noted that the latent influence of Semitic languages on the relationship between mediopassive present and perfect in Hittite might have had a striking counterpart in a possible influence of Indo-European verbal morphology on the Akkadian verbal system. In this language, the form iptanarras "he decides again and again" represents an iterative variation of the present form iptarras "he decides" (Kienast, 2001: 224-225) with an infix -na- that might be related to the Indo-European infix $-n$ - of the Indo-European imperfective. Admittedly, this element -na- could also be interpreted in terms of Semitic morphology and identified as an occurrence of the morph of passive that appears in the Hebrew nif ${ }^{\prime} a l$ or the Arabic seventh form infa' ala. However, even if one considers that at a very early stage in the development of Semitic languages, the various formants were polyvalent, it is hard to conciliate a passive meaning with the iterative value. Therefore, it is preferable to interpret the infix -na-in iptanarras as a remarkable intrusion of the Indo-European morph $-n$ - in the verbal system of Akkadian. 
However, the use Hittite makes of the reflex $n i(n)$ of the Indo-European infix $-n$ - is slightly different since it bears the value of a causative able to transform an intransitive verb into a transitive one: e.g. hark "to get lost" $\longrightarrow$ harni(n)k "to destroy". Therefore, the Indo-European language that seems to have exerted an impact on the use of the infix - $n$ - in Akkadian in order to bring an iterative value is not necessarily Hittite.

\section{Syntax}

One of the many Hittite modal particles is $-k a n$. This particle has been related to the Sanskrit interrogative pronoun kam "whom" or to the Greek conditional particle $\kappa \varepsilon(v) / \kappa \alpha$ (Boley, 1989: 17; 91). Another etymology connects -kan with Hittite katta "down; beneath" or more exactly to kattan, whereof -kan could be the reduced, enclitic form (Pedersen, 1938: 158). Jacqueline Boley does not seem to be very much convinced by those etymologies and she prefers to speak of an "amorphous origin" for this particle (Boley, 1989: 91). According to this scholar, it is precisely because of this amorphous origin that -kan succeeded in superseding many other Hittite particles in the transition from Old to Middle Hittite.

However, functional and semantic criteria suggest a hypothesis relating this word to the Semitic root kwn "to be; to establish" that appears in Akkadian kānu "to make firm", in Ugaritic and Phoenician $k n$ (probably to be vocalized kān) and in Arabic kāna "he was". In Hebrew, some adverbs were derived from this root: kān "here"; kēn "so"; $k \bar{o}<* k \bar{o} n$, same meaning. Admittedly, kān belongs to a later stratum of Hebrew (Mishnaic Hebrew). However, the attestation of a linguistic feature in a state of language that goes back only to the first centuries of the common era does not exclude the possibility to assign an older origin to it, inasmuch as Mishnaic Hebrew probably corresponds to a lower register of Hebrew that was in use in Judaea a long time before its first attestation in relatively late corpora (the Mishnah was compiled at the end of the 2nd century CE).

Semantically speaking, the original value of -kan in Hittite seems to have been a spatial one (Rieken, 2011: 74), like kān "here" in Mishnaic Hebrew. However, the most striking parallelism between Hittite and Semitic languages pertains to a non-spatial value of -kan in order to express a terminative value (Rieken, 2011: 13), which is quite close to the accomplished value of Ugaritic and Phoenician $k n(k \bar{a} n)$ and of Arabic kāna "he was". The compulsory use of -kan with the preterit form (e.g. kuennun-kan "I killed; I have killed") may suggest that the particle reinforces the irreversible nature of the action of killing.

It is worth noting that the Hittite verbal system was able to express the pluperfect using the verb es- "to be" as an auxiliary accompanied by a participle. The use of the particle -kan with the preterit responded to a specific need of the aspectual system of Hittite. Indeed, the Hittite binary system of oppositions between a present-future and a preterit and the consecutive loss of aspectual oppositions (Cowgill, 1979), made it difficult to express a truly perfective value with

TIPA. Travaux interdisciplinaires surr la parole et le langage, 37 I 2021 
grammatical means. Thus, the terminative particle kan stressed the perfective value of the preterit like in Arabic where the scarcity of the tense system is compensated by the use of qad with the perfect in order to express the "cessation with the present" (muntahi fi-l-häadir). The interesting point here is not only the parallelism across the centuries between Hittite and Arabic, but also the recycling of a particle of probable Semitic origin as a typically Indo-European enclitic characterized by its position as the second word of the sentence, immediately after the first stressed word in accordance with Wackernagel's Law (Wackernagel, 1892).

\section{From the Tyrrhenian-Lydian convergence to the Etruscan- Italic convergence}

Among Anatolian languages, Lydian is largely divergent from its cognates from the second millennium BC, as well as from the languages of the Luwian groups attested during the first millennium (Lycian and Milyan). This divergence led Antoine Meillet to think that Lydian and Lycian do not belong to the Indo-European language family although the same scholar recognized that some of their features were reminiscent of Indo-European (Meillet, 1937: 77). However, their Indo-European character is beyond doubt and what made Meillet formulate his wrong judgement is probably the poor knowledge that was available about those languages at the time he wrote. Confronted with Hittite or Luwian, Lydian and Lycian are apparently the result of a secondary evolution that could partly be due to a process of typological convergence toward non-IE surroundings. The same may be assumed regarding Carian, recognized nowadays as an Indo-European language of the Anatolian branch, closely akin to the abovementioned Lycian and Milyan.

More specifically, the idiosyncrasy of Lydian may be due to its location at the western fringe of the Anatolian language continuum rather than to a process of convergence of an alien language toward an Indo-European language pattern, a hypothesis that has been discarded by Harold Craig Melchert (2008: 56). Thus, if Lydian is not the result of the convergence of a nonIE language toward the Anatolian branch of the Indo-European languages, it could at least be the result of the typological convergence of an Anatolian language toward non-IE languages that were spoken west of it.

An opposed convergence process of a non-IE language toward the Anatolian language family can be observed with regard to Etruscan. Leaving aside the "Nostratic" explanation for the occasional similarities of this language with IE, I would like to focus on the convergence process that brought the so-called Tyrrhenian or Proto-Tyrrhenian language family close to the linguistic patterns exhibited by the Anatolian group. This convergence process probably took place before the emigration of the Etruscans from the eastern to the western Mediterranean. From an extralinguistic vantage point the process of linguistic convergence may be paralleled by a cultural encounter, whose deformed echo could be Herodotus' statement on the Lydian

TIPA. Travaux interdisciplinaires surr la parole et le langage, 37 I 2021 
origin of the "Tyrrhenians" (Histories, I, 94) (Briquel, 1991). However, this process was not completed, probably because of the emigration of the population that arrived in Italy around the eighth century BC. Let us try to sketch out some points of convergence between Etruscan and Anatolian languages.

\section{1. Mutual convergence between Anatolian languages and}

\section{Tyrrhenian}

\section{Phonology}

There are some striking similarities between the consonantal system of Lydian and that of Etruscan (also shared with Lycian) (Melchert, 1994: 282). Both languages display a blatant absence of any voiced stops, at least as regards their phonemic status (Melchert, 1994: 329). Lydian [dz] (noted as $<\tau>$ ) that represents a former *[d] before [i], [j] and [u] (Melchert., 1994: 358 ) and [ð] (noted as $<\delta>$ ), an avatar of $*[\mathrm{~d}]$ at the end of the word, are both clear testimonies of the previous existence of a voiced range of stops in Lydian. Lydian and Lycian devoicing of the stops is obviously the product of a secondary evolution, whose prodromes are found in other Anatolian languages. One thinks, for instance, of the Hittite alternation harki-/hargai- "white; clear" < * $H_{2}$ erg- vs. Greek ápyopov. As regards the Anatolian languages of the second millennium $\mathrm{BC}$, the structural drift that brought toward an occasional devoicing in the second millennium BC may be due to the contact with Hurrian, a language that does not seem to have conferred a phonemic status to voiced consonants if it had any at all.

It is symptomatic that both Lycian and Lydian, two languages attested in the first millennium $\mathrm{BC}$, share a common tendency to devoice consonants. This may represent the accomplishment of a drift still latent during the second millennium $\mathrm{BC}$ and probably reactivated as a result of contact with a language where the opposition voiced vs. unvoiced was not phonemic. Let us remind that in linear B, a writing system adapted from a graphemic system conceived to represent an Aegean pre-Indo-European language, the only voiced stop to be expressed graphically is [d].

Another interesting isogloss between Lydian and Etruscan is the existence of a fricative [f] in the two consonant systems. This is all the more striking given that Lycian, an Anatolian language whose attestations are contemporaneous to that of Lydian, lacks this fricative. Admittedly, the Lydian [f] could have at least two origins. It can derive from the conditioned spirantization of $[\mathrm{p}]$, as well as from the unconditioned labiodentalization of a former bilabial sonorant [w] (Melchert, 1994: 335). Both Proto-Anatolian phonemes [p] and [w] could have perfectly survived in the phonemic system of Lydian. However, the contact of this language with an alien language that had a [f] in its consonant system probably triggered a phonemic

TIPA. Travaux interdisciplinaires surr la parole et le langage, 37 I 2021 
knock-on-effect that attracted $[\mathrm{p}]$ in a certain position and $[\mathrm{w}]$ to the same empty cell [f] within the Lydian phonemic system. Furthermore, the grapheme that represents the fricative [f] is the same double beta in both Lydian and Etruscan alphabet. This similitude is certainly due to contact, direct or indirect, between Lydian and Etruscan (Gusmani, 1978).

Lastly, a tendency for the syncope of unaccented vowels appears both in Lydian and Etruscan, triggering the emergence of strange consonant clusters like CCCV: e.g. Lydian bitarvo-

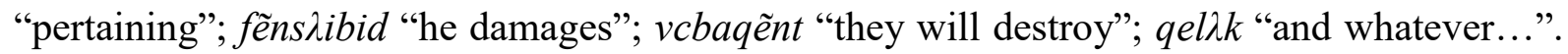
In all these words from the same Lydian-Aramaic bilingual inscription, the sonorant $\langle\lambda\rangle$ may have functioned as a syllabic center. However, since $\langle\lambda\rangle$ was actually a palatalized lateral approximant $[K]$, it is difficult to assign a purely vocalic value to this phoneme. It is perhaps safer to assume that an epenthetic vowel [ə] was included in order to facilitate the pronunciation of this sequence of consonants. Those extremely compact consonant clusters are paralleled in Etruscan where the Greek anthroponym A $A \lambda \varepsilon \dot{\xi} \xi \alpha \nu \delta \rho \varsigma$ has been adapted as Alcsntre. In this language, the use of epenthetic vowels is clearly attested by such graphic variations as Hercle/Hercele "Hercules" (Bonfante, 2002: 80).

\section{Morphology}

A notable isogloss that seems to unite Etruscan and Anatolian declension is the obvious recycling of Anatolian nominal morphs. Whereas the ending $-s /-s$ displays a striking similitude with the Indo-European morph *-es/-os (Hittite -aš), its adjectival counterpart -al used in $-i$ stems, as well as in stems ending with a velar or a liquid, is reminiscent of the possessive suffix $-l i$ that seems to be the origin of the Lydian dative-locative morph $-\lambda$ (Trombetti, 1928: 18; Schmidt, 1968: 235-236). The fact that in Etruscan this morph $-l$ always appears with a preceding $-a$ - is not consonant with the Lydian possessive suffix -li. However, the combination -al- is paralleled by other Anatolian languages: Hittite -al(l)la-, Luwian -alla/i- (Gérard, 2005: 86). In the past, this similitude between the adjectival genitive -al of Etruscan and the Lydian and Luwian facts has been used as an argument to prove that Etruscan was a missing link between the Indo-European and the Caucasian languages or that it was an Indo-European language of the Anatolian branch, whose original type has been affected by various alloglottic influences (Woodhuizen, 1992: 82). In my opinion, however, Etruscan is an Indo-Europeanized language rather than a former Indo-European language that lost its original type. Moreover, the existence of an Etruscan definite accusative ending - ni may also result from ancient contact of Proto-Tyrrhenian with an Indo-European surroundings. This ending seems to be borrowed from the pronominal paradigm of the 1 st pers. sg.:

nominative $m i$

accusative $m i-n i$ 
The fact that the same morph -ni serves to form the definite accusative of the noun and the accusative of the pronoun reminds of similar processes that occurred in various Indo-European languages where the nominal declension has been occasionally reinforced by endings borrowed from the pronominal paradigms. Let us mention, for instance, the genitive ending *-so of the pronouns recycled as a nominal ending in Germanic or the pronominal ending *-oi of the nominative masc. pl. replacing *-ōs in Greek, Latin, Celtic, Baltic and Slavic. (Forston, 2010: 127-129).

By itself, this alternation between nominative $m i$ "I" and accusative mini "me" displays an isogloss more with Anatolian languages. If one assumes that $m i$ goes back to the accusative form *eme/me of the Indo-European pronoun, then the use of an accusative form as a nominative is paralleled by the use of the accusative-dative form amu, originally "me, to me" as a nominative in Lydian (Gérard, 2005: 91-92). Typologically speaking, the distinction between nominative and accusative is more important for such a part of speech as the pronoun than for the category of nouns. Since in Etruscan, there was no distinction between nominative and accusative in the latter part of speech, the need was felt to mark this distinction using a pattern that seems to be borrowed from Indo-European morphology (cf. Old Slavic genitive mene < Proto-Indo-European ${ }^{*} H_{1}$ méne as opposed to the enclitic accusative me). The theoretical possibility of borrowing pronouns from one language to the other has been studied by Sarah Thomason and Daniel L. Everett (Thomason-Everett, 2005). At a later stage, this distinction between nominative $m i$ "I" and accusative mini "me" was transposed to the category of noun according to the above-mentioned Indo-European structural trend that consists in extending occasionally the pronominal declension to the nominal one.

Lastly, the Etruscan dative ending -si seems to contain the dative ending $-i$ attested in all Anatolian languages with the exception of Lydian that recycled the ending $-\lambda$ as a dativelocative. The Etruscan morph $-s i$ seems to be the agglutination of the genitive ending $-s$ with the dative ending $-i$. The contact of the sibilant [s] with the palatal vowel [i] may be held

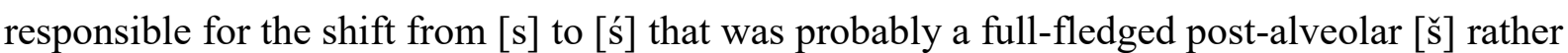
than an apico-alveolar [ś].

\section{2. Mutual convergence between Tyrrhenian (Etruscan) and the}

\section{Italic languages}

As mentioned in the previous section (2.1) the process of convergence of Tyrrhenian seems to have already started in the eastern Mediterranean when the influence exerted on ProtoTyrrhenian by the Anatolian languages of the Indo-European languages constituted the counterpart of the convergence of Lydian toward Proto-Tyrrhenian.

TIPA. Travaux interdisciplinaires surr la parole et le langage, 37 I 2021 


\section{Phonology}

An examination of the synchrony of Italic languages reveals that the impact the Etruscan adstratum exerted on the phonetics of the Italic languages regards mainly the consonant system. However, vowels might have been affected in a double way: as far as they underwent important shifts as a result of the adoption of an Etruscan intensity stress; and perhaps also with respect to the reinterpretation of a sonorant as a group consisting of a vowel followed by a consonant.

vowels

Whereas Indo-European syllabic *[r] and *[1] have been reinterpreted as [-or-]/[-ur-] and [-ol]/ [-ul-] in Italic languages (Leumann, 1963: 64), Latin and Sabellic (Oscan and Umbrian) phonology displays a probable isogloss with Etruscan whenever the Indo-European syllables $*[\mathrm{er}]$ and $*[\mathrm{el}]$ have been reduced to $*[\mathrm{r}]>*\left[{ }^{\circ} \mathrm{r}\right]$ and $*[1]>*\left[{ }^{\circ} 1\right]$ before vowel. In those cases, the reflexes of the syllabic sonorants is [ar] and [al] respectively, rather than [or]/[ur] or [ $\left.{ }^{0} 1\right] /[\mathrm{ul}]$ : e.g. Latin caro/carnis "flesh"; Umbrian karu/karnus "portion"; Oscan carneis, same meaning, instead of a form based on the full grade *ker- of the root (Leumann, 1963: 64-65). This special treatment of $*\left[{ }^{\circ} \mathrm{r}\right]$ and $*\left[{ }^{\circ} 1\right]$ is reminiscent of the value of the syllabic sonorants in Etruscan where the vocalic resonance of the sonorants [1], [r], [m], [n] used as vowels was [a] as shown by the spelling Atlnta for Greek A A $\alpha \lambda \alpha$ óv $\tau$ (Bonfante, 2002: 80).

Broadly speaking, the contact with Etruscan may be held responsible for the increased proportion of [a] in the vocalic system of the Italic languages (Breyer, 1993: 476). Although this phoneme had only a marginal status in the vocalic system of Proto-Indo-European, contact with languages where it displayed a central role may explain that in certain cases this vowel was retained as a default choice. In order to understand to which extent the Italic vocalism has been influenced by the Etruscan one, it is important to remind that Etruscan had no [o] in its phonological system.

\section{consonants}

I would like to focus on an Italic specificity that may be ascribed to the impact of a pre-IE Mediterranean substratum (Risch, 1992: 16) and more specifically to the pressure exerted by Etruscan throughout Italy. It regards the spirantization of voiced aspirates in every position in Oscan, Umbrian and Faliscan, and only at the beginning of the word in Latin and Venetic. The difference in the reflexes of the Indo-European voiced aspirate between the main part of the Italic languages on the one hand and Latin and Venetic on the other hand, can be represented as follows:

IE $* \mathrm{~b}^{\mathrm{h}}>$ Italic [f] vs. Latin [b] (within the word): e.g. Latin faba ( $<$ Proto-Indo-European $* b^{h} a b^{h} \bar{a}$ "bean") vs. (Mettius) Fufetius, that is, Mettís Fufetiis in Oscan (Noonan, 2006: 330) and the 
name of the vestal Fufetia, Latin anthroponyms apparently derived from an unattested form *fafā-, which is the expected Sabellic correlate of Latin faba.

IE $* \mathrm{~d}^{\mathrm{h}}>$ Italic [f] vs. Latin [b]/[d]: e.g. Umbrian rufru "red" vs. Latin ruber; Oscan mefiai vs. Latin mediae

IE *g ${ }^{\text {wh }}>$ Italic [f-] vs. Latin [v]: e.g. Umbrian vufru "vow" (<*PIE *Hlweg $\left.{ }^{h}-r o-\right)$ vs. Latin voveo "I vow"

IE $* \mathrm{~g}^{\mathrm{h}}>$ Italic $[\mathrm{h}]$ vs. [h] in Latin and Venetic: e.g. Latin prehendo < *prae-hendo "I grasp" with -hendo continuing Proto-Indo-European ${ }^{*} g^{h} e d$ - with the infix - $n$ - of the imperfective.

The spirantization of $*\left[\mathrm{~b}^{\mathrm{h}}\right], *\left[\mathrm{~d}^{\mathrm{h}}\right], *\left[\mathrm{~g}^{\mathrm{h}}\right]$ and $*\left[\mathrm{~g}^{\text {wh }}\right]$ in $[\mathrm{f}]$ and $[\mathrm{h}]$, that was restricted to the beginning of the word in Latin and Venetic, is a remarkable case of adaptation to the phonemic system of Etruscan. Indeed, [f] was not part of the original stock of Indo-European consonants. Nor was [h] available after the disappearance of the laryngeals, which might have occurred very early in the specific case of [h] if such is the value to be ascribed to $*\left[\mathrm{H}_{1}\right]$ that is not even attested in Hittite.

The first trigger of the double process of spirantization and devoicing of Indo-European*[ $\left.\mathrm{b}^{\mathrm{h}}\right]$, $*\left[\mathrm{~d}^{\mathrm{h}}\right], *\left[\mathrm{~g}^{\mathrm{h}}\right]$ and $*\left[\mathrm{~g}^{\text {wh }}\right]$ was the incompatibility of this range of voiced aspirates with the phonemic system of Etruscan that did not tolerate voiceness for consonants and fricatives. However, Etruscan had a range of unvoiced aspirates $\left[\mathrm{p}^{\mathrm{h}}\right],\left[\mathrm{t}^{\mathrm{h}}\right],\left[\mathrm{k}^{\mathrm{h}}\right]$ that were inexistent in the Italic languages and whose status is considered to have been only marginal in the primeval phonological system of Proto-Indo-European (Elbourne, 1998). In the negotiation between two apparently incompatible systems, the Sabellic languages and Faliscan do not seem to have reinterpreted the Indo-European-inherited voiced aspirates $*\left[\mathrm{~b}^{\mathrm{h}}\right],{ }^{*}\left[\mathrm{~d}^{\mathrm{h}}\right],{ }^{*}\left[\mathrm{~g}^{\mathrm{h}}\right]$ and ${ }^{*}\left[\mathrm{~g}^{\text {wh }}\right]$ as the Etruscan series of unvoiced aspirates $\left[\mathrm{p}^{\mathrm{h}}\right],\left[\mathrm{t}^{\mathrm{h}}\right],\left[\mathrm{k}^{\mathrm{h}}\right]$ because in the phonemic system of the Italic languages the aspiration was no longer compatible with unvoicedness. Therefore, ${ }^{*}\left[\mathrm{~b}^{\mathrm{h}}\right],{ }^{*}\left[\mathrm{~d}^{\mathrm{h}}\right]$, $*\left[\mathrm{~g}^{\mathrm{h}}\right]$ were probably spirantized as the voiced fricatives * $[\beta], *[ð], *[\gamma]$ that eventually lost their voiceness under the influence of the Etruscan-centered Italic Sprachbund. The devoicing of $*[\beta], *[\gamma], *[\gamma]$ as $*[\varphi], *[\theta], *[\chi]$ was followed by a further adaptation to the sub-system of the Etruscan fricatives. This convergence process led to the merger of the bilabial fricative $*[\varphi]$ and the interdental fricative $*[\theta]$, both inexistent in the Etruscan phonemic system, as the labiodental [f], which is well attested in Etruscan. As for $*[\chi]$, it could also have been reinterpreted as $[\mathrm{h}]$ in order to make it compatible with the articulation habits of the new areal surroundings.

However, Latin and Venetic behaved differently from other Italic languages to which Venetic most probably belonged (Beeler, 1949: 51-57). Thus, Latin and Venetic reinforced the fricatives $[\beta]$ and $[ð]$ resulting from $*\left[\mathrm{~b}^{\mathrm{h}}\right]$ and $*\left[\mathrm{~d}^{\mathrm{h}}\right]$ respectively, as $[\mathrm{b}]$ or $[\mathrm{d}]$ :

Proto-Indo-European $* t e b^{h} e i>$ Latin tibi as against tefei in Oscan and tefe in Umbrian;

TIPA. Travaux interdisciplinaires surr la parole et le langage, 37 | 2021 
Proto-Italic *loiðeros "free" > Venetic louderobos "to the (free) children" (dative pl.) as against Old Latin loeber "free" (later līber) and Oscan lúvfreís (genitive sg.);

Proto-Indo-European *med ${ }^{h}$ io-s $>$ *meðios $>$ Latin medius.

The result of this reinforcement of the fricatives in Latin and Venetic is quite similar to the reflex of the Indo-European aspirates $*\left[\mathrm{~b}^{\mathrm{h}}\right]$ and $*\left[\mathrm{~d}^{\mathrm{h}}\right]$ as $[\mathrm{b}]$ and $[\mathrm{d}]$ in most Indo-European languages. However, in Latin and Venetic, this result is not due to a mere disappearance of the coefficient of aspiration $\left.*^{*}{ }^{-}\right]$but to a secondary evolution of the fricatives that developed under the influence of the element $*\left[-{ }^{h}\right]$.

Thus, the spirantization process in Latin and Venetic was not a one-way process inasmuch as the fricatives $[\beta]$ and $[ð]$ were reinterpreted as stops either in the same place of articulation $([\beta]$ $>$ [b] like in Latin tibi; [ð] > [d] like in Venetic louderobos) or with a shift from the dental to the bilabial as in Latin loeber. Whatever it may be, the voicing was preserved in Latin and Venetic and this conservative feature in the treatment of the voiced aspirate could corroborate the assumption that Venetic represents an archaic and conservative blend of Italic (Euler, 1993). In Sabellic, Faliscan and at the beginning of the word in Latin, however, the correlation of voicing was lost, probably as a result of strong exposure to the Etruscan-speaking surroundings. In this distribution between Italic languages more Etruscized in their treatment of the voiced aspirates and the less Etruscized, Latin holds an odd position inasmuch as it behaves like the more Etruscized Sabellic and Faliscan as far as the initial of the word is concerned and in a less Etruscized way (as shown by the preservation of the correlation of voicing in $[\beta]$ and [ð]) within the word.

The contrast between the Italic languages whose consonantism was strongly adapted to the Etruscan one, and those more conservative is perfectly understandable in the case of Venetic, a language that was exposed to contact with other Indo-European languages rather than with those pertaining to the Italic branch.

Interestingly enough, the [b] stop obtained by the reinforcement of [ $\beta]$ (Latin tibi) or [ð] was hardly represented among the primeval phonemic stock of Proto-Indo-European. In a certain sense, the $[\mathrm{b}]$ constituted an empty cell in the phonemic system of Proto-Italic, which provoked a knock-on effect. Consequently, the fricatives within the word were reinterpreted as a consonant not so much represented in the inherited system. In the process of adaptation to the alien Tyrrhenian language with which Proto-Italic was in contact, the spirantization was the result of this encounter between two different phonemic systems. However, the process of adaptation of Proto-Italic toward the phonology of Tyrrhenian was only partial because it did not involve the neutralization of the correlation of voicing. Moreover, it seems that in the Sabellic languages at least, as well as in Faliscan, the fricative represented by the grapheme $<_{\mathrm{F}}>$

TIPA. Travaux interdisciplinaires surr la parole et le langage, 37 I 2021 
within the word was actually a voiced phoneme (probably $[\beta]$ ), as shown by some spelling alternations between $[\beta]$ and $[F]$ in Umbrian (Meiser, 1986: 73-74).

Even Faliscan, which under other aspects is probably the Italic language closest to Latin (to the extent that is has often been considered a dialect of Latin), shared with Sabellic a more intensive exposure to the influence exerted by Etruscan, especially as regards the spirantization of $*\left[b^{\mathrm{h}}\right]$, $*\left[\mathrm{~d}^{\mathrm{h}}\right], *\left[\mathrm{~g}^{\mathrm{h}}\right]$ and $*\left[\mathrm{~g}^{\mathrm{wh}}\right]$.

The lesser exposure of Latin to the phonetic influence of Etruscan may be explained in extralinguistic terms. Indeed, the people of Falerii were integrated in the Etruscan league whereas all the history of archaic Rome since the expulsion of the Etruscan kings in 509 BC at least, reveals a strong antagonism toward the Etruscan hegemony in Latium. The phonetic conservatism of Latin is evidence for a linguistic archaism reflecting a state of relative isolation, which might have been partly deliberate.

Giacomo Devoto proposed to ascribe the phonemic divergence of Latin on the one hand and of Sabellic on the other hand, to the fact that Latin and Sabellic did not originally pertain to the same branch in the Central European homeland of the European branch of Indo-European languages (Devoto, 1929: 240). There, Italic, Celtic, Germanic and Illyrian seemed to have been in contact for quite a long time before the people who eventually became the Italics arrived in the Peninsula (Krahe, 1954: 79-83). Once transplanted in Italy, Latin could have experienced a process of convergence toward Sabellic. However, this convergence was only partial, which could explain the specificity of Latin not only as regards the reflexes of $*\left[b^{\mathrm{h}}\right],{ }^{*}\left[\mathrm{~d}^{\mathrm{h}}\right]$ within the word, but also under many other aspects pertaining to both phonology and morphology (Battisti, 1959: 117-122).

\section{Prosody}

One of the structural influences that Etruscan probably exerted on the vocalism of Latin and other Italic languages is connected with the adoption of a strong initial stress, which triggered the closing of the unstressed vowel (apophony). In Etruscan, this stress was far stronger (to the extent that it caused the syncope of the unstressed vowels (Niedermann, 1953: 36-42; Battisti, 1959: 68). Therefore, it is possible to assume that the epicenter of the phenomenon was primarily connected with Etruscan rather than with Latin or other Italic languages. In Sabellic, the phenomenon seems to have been even stronger (Meillet, 1931: 55). In Venetic, however, the intensity of the stress seems to have been felt to a lesser extent (Lejeune, 1974: 125; 129), probably because this language, though exposed to Etruscan influence (as shown by the adoption of an Etruscan alphabet in order to write in Venetic), was not directly integrated in a bilingual horizon. It could have been nothing more than a diglossic situation whereby only the Venetic “clerks", as Lejeune called them (Lejeune, 1974: 141), knew Etruscan, the hegemonic 
language of Italy around $500 \mathrm{BC}$ when the Etruscans exerted their domination from the Po valley till Campania.

The adoption of the intensity stress with the drastic consequences it had on the vocalisms of the languages involved, is probably the result of a situation of Etruscan-Latin, Etruscan-Umbrian, Etruscan-Oscan bilingualism that took place around $500 \mathrm{BC}$, approximately at the time when the stress seems to have been systematized in Etruscan (Hadas-Lebel, 2004: 5-27). However, the strong syncope triggered by the stress could have already begun in the eastern Mediterranean when Proto-Tyrrhenian was in contact with Lydian (see 2.1). Whatever the exact location of this phonetic innovation of Etruscan, it is likely that it occurred in this language before it affected the Italic languages in contact with it (Pfiffig, 1969: 53-54; Breyer, 1993: 490494). In other words, it appears that at a certain stage of their development, Latin, Umbrian and Oscan were pronounced with an Etruscan accent that consisted in adopting a strong intensity stress that was nevertheless combined with the quantitative rhythm within the word.

It has been stated that in Latin, the strong intensity stress at the beginning of the word was not adopted before 300 BCE (Karaseva, 2003: 98-100). Whatever the date of the appearance of such an accent might be, the main point is that the adoption of an intensity stress at the beginning of the word is obviously posterior to a similar phenomenon in Etruscan. It is also worth noting that this initial stress disappeared at a certain stage of the development of Latin, maybe as a result of the contact with Greek, whose consequence could have been not only the disappearance of initial stress, but the adoption or reactivation of a pitch accent (Kent, 1932: $66)$.

\section{Morphology}

Rather than an impact of Etruscan morphology on Latin or other Italic languages, it is likelier to speak of a reverse Indo-Europeanization of Etruscan morphology, especially as regards nominal morphology (Briquel, 1994: 329). However, those processes already started before the translation of Proto-Tyrrhenian to the Western Mediterranean when this language was in close contact with Anatolian languages (see above 2. 1.).

\section{nominal morphology}

Before I try to deal with a possible structural impact of Etruscan on Latin or other Italic languages, it is important to check to which extent Etruscan morphology was already partly Indo-Europeanized, especially as regards nominal morphology. Etruscan influence on Italic languages was probably made easier thanks to that partial Indo-Europeanization that had already brought Tyrrhenian closer to the structural type of Indo-European languages. In other words, the interaction between Etruscan and its Italic surroundings may be conceived as a convergence process, which reached its ultimate stage during the "second Latin-Etruscan bilingualism" (Hadas-Lebel, 2004: 29-51; 259-292). 
Beside this structural impact exerted by Anatolian languages in general and by Lydian in particular, it is worth noting that among the endings of the Etruscan nominal paradigm, the morph of the locative (sg. and pl.) -thi (- $\theta \mathrm{l})$ (with its allophone $-t i$ and $-\theta$ ) is quite reminiscent of the locative suffix $-\theta_{\mathrm{r}}$ in ancient Greek (Trombetti, 1928: 15-16). This locative suffix $-\theta_{\mathrm{r}}$ is the reflex of the zero-grade of $*-d^{h} e i$ present in * $k^{w} u-d^{h} e i$ "where?" > Latin $u b \vec{\imath}$ ? Alfredo Trombetti who tried to find as many connections as possible between Indo-European and Etruscan (which he considered loosely akin to the Indo-European language family) did not retain this isogloss because in his opinion, it was shared with many other alien languages. However, all the parallels he tries to find among the languages of the world appear with the form - $t$. In other words, they are not identical with the Etruscan archimorpheme -thi, but with one of its allophone.

It is difficult to determine whether the possible adoption of the Greek locative suffix $-\theta_{1}$ took place in the eastern Mediterranean when Proto-Tyrrhenian was already in contact with Greek or in the western Mediterranean where the contact was continued (although with other Greek dialects). Anyway, the Etruscan nominal paradigms were already Indo-Europeanized when this language entered in contact with the Italic ramification of Indo-European. Yet the functioning of the Etruscan nominal declension displays some clear differences from the Indo-European type. First of all, it obeys an agglutinative rather than a flexional logic inasmuch as the same endings are added to both the singular and the plural. Second, there is no distinction between nominative and accusative although the definite accusative mini, which I have tried to connect with an Anatolian influence, introduces a secondary distinction between the nominative and the accusative.

Another evidence of Indo-Europeanization in Etruscan declension is the occasional use of an ending -s, especially in theonyms (Tinś; Fufluns; Nethuns; Selvans; Sethlans; Turms; Cilens), titles (Lars) or anthroponyms (Aruns). Giuliano Bonfante considers the use of this $-s$ ending mysterious (Bonfante, 2002: 86). In this specific instance, the mystery consists in the fact that this morph is alien and nevertheless integrated within the morphological system of the language. The trigger for this hybridization might have been the borrowing of theonyms like Neptunus or Silvanus where the Latin ending $-s$ was perceived as an integral part of the name. After more and more Italic theonyms entered Etruscan, this $-s$ has been probably perceived as a characteristic of this specific class of names. Moreover, it was used in order to transform a genitive form ending in -al into a nominative. Thus, the nominative papals "grandson" was derived from the genitive papal of papa "grandfather" (Bonfante, 2002: 86).

Conversely, the declension systems of Faliscan and Sabellic seem to have been influenced by Etruscan nominal morphology. The fact that among the various possible endings for the genitive in the Faliscan thematic declension, -sio was often preferred, especially when referring to personal ownership, may have been triggered by the existence of a possessive suffix $-s a /-s a$ in Etruscan (Devine, 1970: 33). 
The influence of Etruscan may also be held responsible for the fact that within the Italic branch, the Sabellic languages have a genitive ending in $-s$ rather than the $-\bar{\imath}$ ending attested in Latin, Faliscan, Venetic and Messapian (Lejeune, 1974: 92). The use of Oscan -eis and Umbrian -er $<-e s<*$-eis (borrowed from the genitive ending $*_{-}$ois/-eis of the $-i$ - stems of the athematic declension) instead of $-\bar{l}$ may reflect an analogical process according to which the genitive ending $-s$ of the feminine in $-a$ and of the athematic declension has been extended to the thematic one. The pressure of the Etruscan genitive ending $-s /-s$ may have been determinant for this preference for the athematic genitive ending -es instead of the thematic ending $-\bar{l}$.

It is also tempting to consider with Breyer that the suffix - $\bar{a}$ lis of such adjectives as comitialis "related to comitia" or capitalis "related to the head", which is dissimilated in -äris after a root containing [1]), is a morphological borrowing from Etruscan (Breyer, 1993: 499-500). Manu Leumann noted that it is paralleled in Oscan and does not exclude a kinship with the Greek suffix $-\eta \lambda-<-\bar{\alpha} \lambda$ - of $\tau \eta \lambda$-1кó $\varsigma<\tau \bar{\alpha} \lambda$-1кó $\varsigma$ "of such a size" (Leumann, 1963: 235). The latter etymology is not so convincing because $\tau \eta \lambda$-1кó $\varsigma$ is after all quite marginal in Greek so that neither the common Indo-European origin of Italic and Greek nor subsequent contacts between the two branches could explain the extraordinary success that $-\bar{a} l i s /-\bar{a} r i s$ enjoyed in Latin. The assumption according to which the $-\bar{a}$ - of the suffix represents the ending $-a<-\bar{a}$ is not likely because many adjectives in -ălis/-āris are derived from substantives belonging to other morphological classes than the Latin 1st declension. Moreover, the existence of forms without the -is ending of the second class of adjectives like vectigal "tribute" or pulvinar "cushion for the exhibition of the statues of the gods" could be considered not as a back formation from vectigalis or *pulvinaris, as commonly thought, but as the primeval form wherefrom the forms in $-\bar{a} l i s /-\bar{a} r i s$ have been derived. If so, it is very tempting to recognize in those substantive endings in -al or in - ar $<-a l$ the -al ending of the Etruscan genitive. This is all the more tempting in that such a word as bacchanal "feast in honor of Bacchus" is paralleled by Etruscan paqan $\alpha$ "bacchic" or "bacchanal" where one can recognize the suffix -na expressing possession or reference and the lexical element Paxa "Bacchus" (Pfiffig, 1969: 93; Bonfante, 2002: 99). If so, the Latin substantive bacchanal is likely to contain two Etruscan suffixes combined together according to the logic of agglutination that characterizes Etruscan morphology. The traditional etymology that views bacchanal as derived from baccha "feminine bacchant" (Ernout-Meillet, 1956: 63) may be challenged by the attempt to connect Latin bacchanal with the abovementioned Etruscan term paxana (Breyer, 1993: 500-502). This could explain the presence of the suffix -na- that seemed an anomaly to Alfred Ernout and Antoine Meillet who thought that the expected form would have been *bacchalia rather than bacchanalia. What Ernout and Meillet considered an anomaly from the vantage point of a purely Latin etymology may prove quite consistent with the system of Latin, provided bacchanal should be analyzed as the combination of an Etruscan etymon paxana with a suffix $-\bar{a} l i s$ where the element $-\bar{a} l$ - is probably also of Etruscan origin. 
Furthermore, in vectigal "tribute", where the presence of the - $g$ - is difficult to explain, the use of the Etruscan genitive ending - al reinterpreted as an adjectival suffix in Latin makes sense in terms of Etruscan grammar. As mentioned above, according to the rules of Etruscan nominal morphology, after a velar consonant ( $k$ or $\chi$ ), the -al ending of the genitive is preferred to the $s$ ending. Admittedly, the phonemic system of Etruscan does not tolerate any voiced stop, so that the presence of $[\mathrm{g}]$ at the end of the semantic part of the word (vectig-) seems to exclude an Etruscan etymology. However, the most important thing here is perhaps not the voicing of [g], but rather the fact that the Etruscan morphological rule requiring the use of a genitive ending $-a l$ instead of $-s$ after a velar consonant seems to have been at play even in a word that was not necessarily of Etruscan origin. Incidentally, some later attestations of Etruscan reveal that in contact with Latin, the phonemic system of Etruscan seems to have adopted the phonemic feature of voicing under certain conditions (Pfiffig, 1969: 36-38; Devine, 1974: 144-151; Hadas-Lebel, 2004: 312-313). Thus, it is tempting to consider that the etymon vectigal of vectigal (aes) "tribute money" represents a substantive containing the Etruscan genitive -al ending that was reinterpreted as an adjective once integrated within the linguistic system of Latin. This morphological analysis that insists on the hybrid character of the word does not preclude Julius Pokorny's etymology who wanted to recognize the Latin word vectis "lever" as the word wherefrom vectigal was derived (Pokorny, 1959: 1118).

Lastly, Carlo Battisti has pointed at a possible influence exerted by the Etruscan morph -na/ana on the Latin suffix -ānus. Here the convergence of Latin toward Etruscan could have triggered the amazing productivity of -ānus in the former language (Battisti, 1959: 359-384). By itself, this suffix - $\bar{a} n u s$ is an amalgam of Indo-European morphs. It contains the element no- that Hans Krahe recognized as an isogloss between Italic and Germanic (Krahe, 1954: 73). However, what is at stake in Carlo Battisti's thesis is the importance bestowed on an IndoEuropean suffix once it has been considered a functional equivalent of Etruscan -na/-ana.

\section{verbal morphology}

The verbal system of the Italic languages does not display many signs of morphological hybridization with the non-IE Etruscan adstratum. Conversely, Etruscan does not seem to have been very much influenced by the Indo-European languages with which it stayed in contact throughout its history. Admittedly, our information about the Etruscan verbal system is quite fragmentary due to the very nature of our corpora: funeral inscriptions; dedicatory formulas; vase graffiti. Nevertheless, an interesting point of convergence may be observed between Latin and Etruscan as regards the system of the participle.

A comparison of the Latin participle system with the Venetic one reveals that Latin has lost its present mediopassive participles in -mnos (cf. Sanskrit -mānah; Greek - $\mu \varepsilon v o \varsigma$ ) that seem to have been maintained as a full-fledged part of the verbal system in Venetic (Lejeune, 1974: 83). In Latin, the parallel of this suffix is a merely nominal suffix $-m n-o-s$ that was 
degrammaticalized as in the case of alumnus "nursling", perhaps a former present passive participle of alere "to nourish". This downgrading of a full-fledged participial form to the status of a substantive may reflect the influence of Etruscan where the present passive participle is the only lacking category in a participial system that was otherwise well-furnished with present active participles in - $a s$ and -an, past active participles in - $\theta a s$ and - $a s a$, past passive participles in - $u$ (Bonfante, 2002: 101-103). A similar pressure of the participial system of Etruscan seems to have been at work in Sabellic where no apparent traces of a past passive participle have been left. On the other hand, a further impact of Etruscan may be recognized in Oscan where an active participle in -us continuing the Indo-European ending *-wes/-wos/-us and parallel to the ending of the Greek perfect active participle $-(F) \omega ́ \varsigma /-v i ̃ \alpha /-(F)$ ó $\varsigma$ seems to be attested through the verbal adjective sipus < *sep-wos "having known". This form is derived from the full grade realization $*_{s e p} \bar{e}-<$ Indo-European ${ }^{*} s_{e} H_{l} p$ whose zero-grade equivalent $*_{s} H_{l} p$-yields the Latin sapere "to have taste" (Wallace, 1985; Untermann, 2000: 677). The fact that this form has subsisted in Oscan, as well as in Volscian, may be due to the pressure of the Etruscan system where the morphological category of the past active participle was very vivid (to the extent that the two morphs - Aas and -asa expressed this value).

Lastly, the ambivalent status of the deponent verb in Latin and Sabellic may be due to an Etruscan influence. As in the case of the Etruscan past participle in $-u$, which has a passive (inactive) diathesis when the verb is transitive, and an active one when it is intransitive (Bonfante, 2002: 102), a Latin or Sabellic passive is a full-fledged passive when it constitutes the transformation of a transitive active (e.g. Latin vincitur "he is defeated"; Oscan vincter "he is defeated") and an active when it has no active-transitive counterpart: e.g. Latin precatur "he begs"; Umbrian persnihimu "let him beg" (Buck, 2004: 212). The shift from passive (inactive) to active whenever the verb is not transitive, may also give an account of the impersonal passive where the meaning is totally active: Latin itur "there is an action of going"; Oscan sakarater "there is a sacrifice". This opposition where the passive is the basic category and the mediopassive deponent a derived one strongly contrasts with the situation in other IndoEuropean languages like Greek or Sanskrit where the passive is a semantic specification of the middle voice (Kurzová, 1993: 157-171).

\section{Syntax}

The syntax of Archaic Latin does not seem to display any manifest mark of hybridization with Etruscan. On the other hand, the Etruscan coordinate conjunction $-c$ seems to come from a contacting Indo-European language where Indo-European $*_{-} k^{w} e$ was reduced to -ke (Venetic) or maintained as -que [ $\left.\mathrm{k}^{\mathrm{w}} \mathrm{e}\right]$ (Latin) rather than - $p$ like in Sabellic (-pe/-pei in Umbrian). Besides, $-c$ is an allophone of -que in Latin itself, as shown by the euphonic alternation between neque (before a vowel) and nec (before a consonant) or atque and $a c$. The use of Etruscan $-c$ is strongly reminiscent of that of -que in Archaic Latin where the coordinate conjunction is repeated after

TIPA. Travaux interdisciplinaires surr la parole et le langage, 37 I 2021 
each of the coordinated terms: apac atic (that is, apa-c ati-c) "father and mother" like paterque materque (Bonfante, 2002: 104).

\section{Conclusion}

This survey brought us from the first half of the second millennium $\mathrm{BC}$ to the beginning of the Christian era when Etruscan and Italic languages other than Latin disappeared from the Italian linguistic horizon. The Semitic-Anatolian convergence processes that occurred during the second millennium BC gave their specific touch to the Indo-European languages of Asia Minor (especially as far as the contact-induced preservation of the laryngeal consonants is concerned). Lydian, a later development of the Anatolian branch of the Indo-European language, probably exerted no less influence on the Tyrrhenian language of the Northern Aegean (Lemnian) than it received influences from that language family. Once partially "Indo-Europeanized", Tyrrhenian seems to have been brought to Italy where the Indo-Europeanization process was continued. However, it was counterbalanced by a strong Thyrrenization/Etruscization of the Italic languages that were part and parcel of the Sprachbund where the Etruscan language played a significant role.

The plays of mutual influences that occurred first in Anatolia and Western Asia in the second millennium BC, second on the shore of the Aegean in the first half of the first millennium BC and lastly, in Italy in the second half of the first millennium BC had deep typological implications especially as far as the morphophonemic dimension is concerned. As for the interface between Indo-Europeanized Etruscan and the Etruscized Italic languages, it was very intense especially as far as Sabellic and Faliscan were concerned. However, Latin itself was also deeply influenced by Etruscan. The facility with which Etruscan was able to exert such a deep influence on the Indo-European languages of ancient Italy may be due to the fact that at the time of the arrival of the Tyrrhenians in Italy before $700 \mathrm{BC}$ or maybe earlier, Etruscan was sufficiently Indo-Europeanized as a result of the previous contacts of Aegean Tyrrhenian (Lemnian) with Lydian. This is an important theoretical point in the issue of mutual convergence: a language is likelier to influence an alien language not genetically related to it whenever it had undergone a first wave of influence from the language it is expected to influence or from a language of the branch it influences. In other words the concept of mutual convergence may be considered diachronically an alternation of reciprocal influences: first Indo-European Lydian influenced Tyrrhenian, then Tyrrhenian in the guise of Etruscan influenced the Italic languages until one of the latter, Latin, totally absorbed Etruscan at the very beginning of the Christian era. However, in spite of this resorption of Etruscan in the linguistic horizon of ancient Italy, Latin preserved in its grammatical system and in its lexicon a strong imprint of the partially Indo-Europeanized language of the people who were the rulers of significant parts of ancient Italy before the emergence of Rome as a local power and of Latin as the language of all the Italians, whether Roman or provincial.

TIPA. Travaux interdisciplinaires surr la parole et le langage, 37 I 2021 
Adams, D. Q. (2013) A Dictionary of Tocharian B Revised and Greatly Enlarged, Amsterdam. New York: Rodopi.

Andersen, H. (2003) Introduction in Andersen H. (ed.), Language Contacts in Prehistory: Studies in Stratigraphy, Amsterdam. Philadelphia: John Benjamins, p. 1-10.

Aslanov, C. (2013) Northwest Semitic Structural Influences on Archaic Greek: A Reassessment, Judaica Petropolitana, 1, p. 17-33.

Battisti, C. (1959) Sostrati e parastrati nell'Italia preistorica, Florence: Felice Le Monnier.

Beeler, M.S. (1949) The Venetic Language, Berkeley. Los Angeles: University of California Press.

Benveniste, E. (1953) La flexion pronominale en hittite, Language, 29, 3, p. 255-262.

Boley, J. (1989) The Sentence Particles and the Place Words in Old and Middle Hittite, Innsbruck: Innsbrucker Beiträge zur Sprachwissenschaft.

Bonfante, G. \& L. Bonfante, (2002) The Etruscan Language: An Introduction, $2^{\text {nd }}$ ed. $\left(1^{\text {st }}\right.$ ed. 1983), Manchester: Manchester University Press.

Breyer, G. (1993) Etruskisches Sprachgut im lateinischen unter Auschluss des spezifischen onomastischen Bereiches, Leuven: Peeters.

Briquel, D. (1991) L'origine lydienne des Étrusques. Histoire du thème dans la littérature antique, Rome: École Française de Rome.

Briquel, D. (1994) Étrusque et indo-européen, in Bader, F. (ed.), Les langues indo-européennes, Paris: CNRS éditions, p. 319-330.

Buck, C.D. (1904) A Grammar of Oscan and Umbrian, Boston: Ginn.

Cowgill, W. (1979) Anatolian hi-Conjugation and Indo-European Perfect: Instalment II, in Neu E. \& W. Meid (eds.), Hethitisch und Indogermanisch: Vergleichende Studien zur historischen Grammatik und zur dialektgeographischen Stellung der indogermanischen Sprachgruppe Altkleinasiens, Innsbruck: Innsbrucker Beiträge zur Sprachwissenschaft, p. 25-39.

Cunliffe, B. (2008) Europe between the Oceans. Themes and Variations: 9000 BC-AD 1000, New Haven. London: Yale University Press, p. 96-105.

Dercksen, J.G. (2007) On Anatolian Loanwords in Akkadian Texts from Kültepe, Zeitschrift für Assyriologie, 97, p. 26-46.

TIPA. Travaux interdisciplinaires surr la parole et le langage, 37 I 2021 
Devine, A.M. (1970) The Latin Thematic Genitive Singular, Stanford, CA: Stanford University.

Devine, A.M. (1974) Etruscan Language Studies and Modern Phonology: The Problem of the Aspirates, Studi Etruschi, 42, p. 123-151.

Devoto, G. (1929) Italo-greco e italo-celtico, Archivio Glottologico Italiano, 22-23, p. 200-240.

Dunkel, G.E. (1994) The IE Directive, in Dunkel, G.E. et al. (eds.), Früh-, Mittel-, Spätindogermanisch, Wiesbaden: Dr. Ludwig Reichert Verlag, p. 17-36.

Edzard, L. (1998) Polygenesis, Convergence, and Entropy: An Alternative Model of Linguistic Evolution Applied to Semitic Linguistics, Wiesbaden: Otto Harrassowitz.

Elbourne, P. (1998) Proto-Indo-European Voiceless Aspirates, Historische Sprachforschung/Historical Linguistics, 111, 1, p. 1-30.

Ernout, A. \& A. Meillet (1956) Dictionnaire étymologique de la langue latine: histoire des mots, $4^{\text {th }}$ ed. $\left(1^{\text {st }}\right.$ ed. 1932), Paris: Klincksieck.

Euler, W. (1993) Oskisch-Umbrisch, Venetisch und Lateinisch, in Rix, H. (ed.), OskischUmbrisch. Texte und Grammatik, Wiesbaden: Dr. Ludwig Reichert Verlag, p. 96-105.

Fortson, B.W. IV (2010) Indo-European Language and Culture: An Introduction, $2^{\text {nd }}$ ed. $\left(1^{\text {st }}\right.$ ed. 2004), Oxford: Blackwell.

Friedrich, J. (1969) Churritisch in Altkleinasiatische Sprachen, Leiden-Köln: E.J. Brill, p. 1-30.

Friedrich, J. (1969) Urartäisch in Altkleinasiatische Sprachen, Leiden-Köln: E.J. Brill, p. 3153.

Garbini, G. (1972) Le lingue semitiche: studi di storia linguistica, Naples: Istituto orientale di Napoli.

Gérard, R. (2005) Phonétique et morphologie de la langue lydienne, Leuven: Peeters.

Gusmani, R. (1978) La scrittura lidia, Annali della Scuola Normale Superiore di Pisa, ser. III, 8,3, p. $833-848$.

Hadas-Lebel, J. (2004) Le bilinguisme étrusco-latin contribution à l'étude de la romanisation de l'Étrurie, Leuven. Paris. Dudley, MA: Peeters.

Hyllested, A. (2020) Did Proto-Indo-European Have a Word for Wheat? Hittite šeppit(t)Revisited and the Rise of Post-PIE Cereal Terminology, in Serangeli, M. \& T. Olander (eds.),

TIPA. Travaux interdisciplinaires surr la parole et le langage, 37 I 2021 
Dispersal and Diversification: Linguistic and Archaelogical Perspectives on the Early Stages of Indo-European, Leiden. Boston: Brill, p. 130-142.

Jasanoff, J. (1978) Stative and Middle in Indo-European, Innsbruck: Innsbrucker Beiträge zur Sprachwissenschaft.

Justus, C.F. (1992) The Impact of Non-Indo-European languages on Anatolian, in Polomé, E.C. \& W. Winter (eds.), Reconstructing Languages and Cultures, Berlin-New York, p. 443-468.

Kammenhuber, A. (1979) Direktiv, Terminativ, und/oder Lokativ im Hethitischen, in Neu, E. \& W. Meid(eds.), Hethitisch und Indogermanisch: Vergleichende Studien zur historischen Grammatik und zur dialektgeographischen Stellung der indogermanischen Sprachgruppe Altkleinasiens, Innsbruck: Innsbrucker Beiträge zur Sprachwissenschaft, p. 115-142.

Karaseva, T.A. (2003) Историческая фонетика латинского языка, Moscow: Греколатинский кабинет Ю. А. Шичалина.

Kent, R.G. (1932) The Sounds of Latin: A Descriptive and Historical Phonology, Baltimore, MD: Waverly Press.

Kienast, B. (2001) Historische Semitische Sprachwissenschaft, Wiesbaden: Otto Harrassowitz.

Krahe, H. (1954) Sprache und Vorzeit, Heidelberg: Quelle \& Meyer.

Kronasser, H. (1966) Etymologie der hethitischen Sprache, Wiesbaden: Otto Harrassowitz.

Kurzová, H. (1993) From Indo-European to Latin The Evolution of a Morphosyntactic Type, Amsterdam. Philadelphia: John Benjamins.

Laroche, E. (1970) Études de linguistique anatolienne III, Revue hittite et asianique, 28, p. 2271.

Lejeune, M. (1974) Manuel de la langue vénète, Heidelberg: Carl Winter.

Leumann, M. (1963) Lateinische Laut- und Formenlehre, $5^{\text {th }}$ ed. ( $1^{\text {st }}$ ed. 1926-1928), Munich: C.H. Beck.

Meillet, A. (1931) Esquisse d'une histoire de la langue latine, $2^{\text {nd }}$ ed. (1 ${ }^{\text {st }}$ ed. 1928), Paris: Klincksieck.

Meillet, A. (1937) Introduction à l'étude comparative des langues indo-européennes, $8^{\text {th }}$ ed. ( $1^{\text {st }}$ ed. 1908), Paris: Hachette.

TIPA. Travaux interdisciplinaires surr la parole et le langage, 37 I 2021 
Meiser, G. (1986) Lautgeschichte der umbrischen Sprache, Innsbruck: Innsbrucker Beiträge zur Sprachenwissenschaft.

Melchert, H.C. (1994) Anatolian Historical Phonology, Amsterdam. Atlanta: Rodopi.

Melchert, H.C. (2008) Lydian, in Woodard, R.D. (ed.), The Ancient Languages of Asia Minor, Cambridge, UK. New York: Cambridge University Press, 2008, p. 56-63.

Niedermann, M. (1953) Historische Lautlehre des Lateinischen ( $1^{\text {st }}$ ed. 1907), Heidelberg: Carl Winter.

Noonan, J.D. (2006) Mettius Fufetius in Livy, Classical Antiquity, 25, 2, p. 327-349.

Pedersen, H. (1938) Hittitisch und die anderen indoeuropäischen Sprachen, Copenhagen: Det Kongelige Danske Videnskabernes Selskab.

Pfiffig, A.J. (1969) Die etruskische Sprache: Versuch einer Gesamtdarstellung, Graz: Akademische Druck- u. Verlagsanstalt.

Pinault, G.-J. (2008) Chrestomathie tokharienne: textes et grammaire, Leuven. Paris: Peeters.

Pokorny, J. (1959), Indogermanisches etymologisches Wörterbuch, Bern: Francke.

Rasmussen, J.E. (1999) Selected Papers on Indo-European Linguistics, Copenhagen: Museum Tusculanum Press, p. 67-81.

Rieken, E. (2011) Einführung in die hethitische Sprache und Schrift, Münster: Ugarit-Verlag.

Risch, E. (1992) Die indogermanischen Grundlagen des Lateins, in Panagl, O. \& T. Krisch (eds.), Latein und Indogermanisch (Akten des Kolloquiums der Indogermanischen Gesellschaft, Salzburg, 23.-26. September 1986), Innsbruck: Innsbrucker Beiträge zur Sprachwissenschaft.

Schmidt, G. (1968) Zu den singularischen Genitiven der indogermanischen Personalpronomina, Zeitschrift für vergleichende Sprachforschung, 82, p. 227-250.

Schwyzer, E. (1953) Griechische Grammatik (1. Band: Allgemeiner Teil-LautlehreWortbildung-Flexion), $3^{\text {rd }}$ ed. ( $1^{\text {st }}$ ed. 1939), Munich: C.H Beck.

Speiser, E. A. (1954) The Terminative-Adverbial in Canaanite-Ugaritic and Akkadian, Israel Exploration Journal, 4, 2, p. 108-115.

Talon, P. (2010) L'alternance $m-w$ dans les textes cunéiformes, in Vanseveren, S. (ed.), Calliope. Mélanges de linguistique indo-européenne offerts à Francine Mawet, Leuven: Peeters, p. 199-203. 
Thomason, S.G. \& D.L. Everett (2005) Pronoun Borrowing, Berkeley Linguistic Society, 27, p. 301-315.

Trombetti, A. (1928) La lingua etrusca, Florence: Rinascimento del libro.

Tropper, J. (2000) Ugaritische Grammatik, Münster: Ugarit-Verlag.

Untermann, J. (2000) Wörterbuch des Oskischen-Umbrischen, Heidelberg: Carl Winter.

Ventris, M. \& J. Chadwick (1973) Documents in Mycenaean Greek, $2^{\text {nd }}$ ed. ( $1^{\text {st }}$ éd. 1956), Cambridge, UK: Cambridge University Press.

Wackernagel, J. (1892) Über ein Gesetz der indogermanischen Wortstellung, Indogermanische Forschungen, 1, p. 333-436.

Wallace, R. (1985) Volscian sepu/Oscan sipus, Indogermanische Forschungen, 90, p. 123-128.

Wegner, I. (2000) Hurritisch: eine Einführung, Wiesbaden, Otto Harrassowitz.

Woudhuizen, F.C. (1992) Linguistica tyrrhenica: A Compendium of Recent Results in Etruscan Linguistics, Amsterdam: J.C. Gieben.

Yakubovich, I.S. (2015) The Luwian Language, Oxford Handbooks Online, Oxford: Oxford University Press. Disponible sur : https://www.oxfordhandbooks.com/view/10.1093/oxfordhb/9780199935345.001.0001/oxford hb-9780199935345-e-18 (consulté le 3 juin 2020)

Yoshida, K. (1990) The Hittite Mediopassive in -ri, Berlin. New York: Walter de Gruyter.

Yoshida, K. (2013) The Mirage of Apparent Morphological Correspondence: A Case from Indo-European, in Kikusawa, R. \& L.A. Reid (eds.), Historical Linguistics 2011: Selected Papers from the $20^{\text {th }}$ International Conference on Historical Linguistics, Osaka, 25-30 July 2011, Amsterdam. Philadelphia: John Benjamins, p. 153-172. 